\title{
Doing theology with children: Some challenges for adult theologians
}

\begin{tabular}{|c|c|}
\hline \multicolumn{2}{|c|}{$\begin{array}{l}\text { Author: } \\
\text { Jan Grobbelaar }{ }^{1} \text { (D) }\end{array}$} \\
\hline \multicolumn{2}{|c|}{$\begin{array}{l}\text { Affiliation: } \\
\text { 1Department of Practical } \\
\text { Theology, Faculty of } \\
\text { Theology, University of } \\
\text { Pretoria, Pretoria, } \\
\text { South Africa }\end{array}$} \\
\hline \multicolumn{2}{|c|}{$\begin{array}{l}\text { Research Project Registration: } \\
\text { Project Leader: S.F. de Beer } \\
\text { Project Number: } 86233689\end{array}$} \\
\hline \multicolumn{2}{|c|}{$\begin{array}{l}\text { Description: } \\
\text { This research is part of the } \\
\text { research project, 'Children, } \\
\text { Faith and Society', directed } \\
\text { by Prof Stephan de Beer, } \\
\text { director of the Centre for } \\
\text { Contextual Ministry and } \\
\text { associate professor in the } \\
\text { Department of Practical } \\
\text { Theology, Faculty of Theology } \\
\text { and Religion, University of } \\
\text { Pretoria, South Africa. }\end{array}$} \\
\hline \multicolumn{2}{|c|}{$\begin{array}{l}\text { Corresponding author: } \\
\text { Jan Grobbelaar, } \\
\text { jgrobbelaar@petracol.org.za }\end{array}$} \\
\hline \multicolumn{2}{|c|}{$\begin{array}{l}\text { Dates: } \\
\text { Received: } 02 \text { July } 2019 \\
\text { Accepted: } 03 \text { Oct. } 2019 \\
\text { Published: } 12 \text { Dec. } 2019\end{array}$} \\
\hline \multicolumn{2}{|c|}{$\begin{array}{l}\text { How to cite this article: } \\
\text { Grobbelaar, J., 2019, 'Doing } \\
\text { theology with children: Some } \\
\text { challenges for adult } \\
\text { theologians', HTS Teologiese } \\
\text { Studies/Theological Studies } \\
75(1) \text {, a5636. https://doi.org/ } \\
\text { 10.4102/hts.v75i1.5636 }\end{array}$} \\
\hline \multicolumn{2}{|c|}{$\begin{array}{l}\text { Copyright: } \\
\text { (C) 2019. The Authors } \\
\text { Licensee: AOSIS. This } \\
\text { is licensed under the } \\
\text { Creative Commons } \\
\text { Attribution License. }\end{array}$} \\
\hline \multicolumn{2}{|l|}{ Read online: } \\
\hline 回的回 & $\begin{array}{l}\text { Scan this QR } \\
\text { code with your } \\
\text { smart phone or } \\
\text { mobile device } \\
\text { to read online. }\end{array}$ \\
\hline
\end{tabular}

Doing theology with children, which includes children as equal participants in the process, is no easy task. Adult theologians face many challenges in becoming involved in doing theology with children. The probing question is: What are these challenges? This article identifies and discusses a few of them. It does not provide an exhaustive list, nor does it discuss each challenge in detail, although more attention is given to the important and crucial challenge to scrutinise our conceptions of childhood. It rather wants to stimulate a conversation about why it is difficult to involve children as equal partners in doing theology and in theological research.

Keywords: Child; Children; Childhood; Child theology; Childist theology; Theologies of childhood; Epistemology.

\section{Introduction}

This article forms part of a collection of articles with the aim of giving ample attention to methodologies of doing theology with children which enhances the agency, collaboration and participation of children themselves as subjects and co-researchers in doing theology. Thus, children doing theology liberates them from their imprisonment and suffering from objectification (cf. Konz 2017:137-140) by theological research. It is a search for methodologies of doing theology which will affirm the human dignity of children, of people younger than 18 years, and thereby restore and empower them as image-bearers of God who can contribute their own insights as equal subjects in doing theology.

The aim of this article is different from the other articles of this collection. It does not formulate any methodology of doing theology with children. The article rather takes one step back by asking some important preliminary questions: why are we still seeking for methodologies of doing theology with children after 20 centuries of theologising, as in this special collection of articles? Why are we struggling to include children's agency in our ways of doing theology? In a paradoxical way this article may contribute to developing methodologies for doing theology with children by turning the focus away from children to adult theologians. This focus change is necessary because restoration in doing theology which includes children as co-theologians is not only important for children but also for adult theologians.

This is how liberation often works. The liberator should also be liberated. The emancipator has also to be emancipated. We can only have methodologies of doing theology which liberate children from their exclusion as equal participants, if the adult theologians are also liberated in this process from the obstacles that may make it difficult or even prevent them from accepting children as their co-theologians. This is how all theology, also doing theology with children, starts: with the conversion of the adult theologian. As Jesus clearly stated in Matthew 18:3 (English Standard Version [ESV]), '[t]ruly, I say to you, unless you turn and become like children, you will never enter the kingdom of heaven'.

Gutierrez's (1990) apt description of conversion in connection with doing liberation theology with the poor is also applicable to doing theology with children:

Conversion means leaving one's own way (see Lk 10:25-37) and entering upon the way of the other, the neighbor, and especially of the poor [children] in whom we encounter the Lord (see Mt 25:31-45). (n.p.)

Encountering the Lord is also part of entering upon the way of the children. In a pronouncement similar in sentiment to Matthew 25:31-45, Jesus said (Mt 18:5), '[w] hoever receives one such child in my name receives me'.

Note: Doing Theology with Children: Exploring Emancipatory Methodologies, sub-edited by Stephan de Beer (UP Centre for Contextual Ministry) and Hannelie Yates (North-West University). 
Doing theology with children is a profound theological activity, it is encountering God. It is playing 'host to God himself [sic]' (Nolland 1993:521). This hosting of God through children never leaves your life untouched. Therefore, the implementation of child inclusive methodologies of doing theology is a reciprocal process: it brings liberation for both children and adult theologians. Berryman (2013) stressed the benefits of this reciprocal process, stating the following:

[T]heologizing with children is conceived of as a spiritual practice for the mutual benefit of both the children and adults involved. The benefit for adults is that being in touch with children benefits their spiritual maturity, as Jesus observed. The benefit for the children is that when adults understand better about 'becoming like a child' they are better able to mentor children, which in turn helps the children to be more fully themselves, which in turn again helps make them better mentors to adults. (Loc. 4295-4296)

Surely, this mutual process of doing theology does not come easy. There are multiple reasons why adult theologians may struggle to involve children as subjects in doing theology. Some of the challenges that adult theologians face in doing theology with children as their co-participants are now identified and discussed.

\section{The challenge of relating children and theology with each other}

One of the challenges that adult theologians confront is how to relate children and theology with each other. It seems that for many years there was almost no relationship between these two domains. One reason for this situation comes to the fore in Hendrick's (1992:1) statement that exactly as women 'have been "hidden from history", so children have been "kept from history"' and '[p]rior to the 1970s very little had been written about either children as people or childhood as a condition...' The same situation existed in almost all theological disciplines. Except in pastoral counselling and religious/Christian education, the topic of children was mostly marginalised in theological and religious research (cf. Bunge 2001:3-4, 2006:551, 2008:xv, 2012:4; Cooey 2010; DeVries 2001:162; Grobbelaar 2016a:11-12; Miller-McLemore 2003:xxii).

Under the influence of especially female voices such as Marcia Bunge, Danna Fewell, Bonnie Miller-McLemore, Joyce Mercer, Kristin Herzog, Sharon Betsworth, Judith Parker and Laurel Koepf Taylor, more interest in theological studies regarding children developed since the beginning of the 21st century. Over the last decade serious theological research about children and childhood has accelerated, especially amongst biblical scholars, to such a degree that Parker (2019:130) expressed the opinion that '[t]he study of children in the Hebrew Bible has come of age'. The growth in this academic field already necessitates the development and acceptance of shared language, especially the adoption of a single nomenclature that will help scholars to clearly express the nature and characteristics of their work. In this regard Parker (2019; cf. Betsworth \& Parker 2019:2-3;
Elkins \& Parker 2016:422-433; Garroway 2018:1-6) made a strong case for accepting 'childist' as the term for research in the biblical sciences intentionally focussing on children. 'At its core, childist theory addresses issues raised by its elder hermeneutic: feminist theory. Like feminist theory, it seeks to assign a voice to the silent other' (Garroway 2018:3).

Children and theology are related with each other in more ways than in the expression childist theology (cf. Grobbelaar 2016b:51-91). According to Bunge (2006:569-570), these two words can be combined in the following ways:

- child theologies

- theologies of childhood

- theologies for children

- children's theology.

Iversen, Mitchell and Pollard (2009:11) even add concepts such as 'Theologizing with Children', 'Philosophizing with Children' and 'Philosophy for Children'. It is not always easy to differentiate between these concepts. Although according to Iversen et al. (2009):

$[I] \mathrm{t}$ is often nothing much more than a matter of labelling, there are indeed some important differences in focus. What all share, however, is awe at the way children deal with the questions posed by existence. (p. 11)

In child theologies, 'children become the hermeneutical lens through which you explore God and God's way of doing things to come to a better understanding of God and God's kingdom' (Grobbelaar 2016b:72). In childist theology, the main focus is the interpretation of Biblical texts in a childcentred way, whilst child theology, in contrast, explores the whole field of theology and all the practices of the church and the Christian life through children as the hermeneutical lens (Bunge 2016:98; Grobbelaar 2016b:72). Theologies of childhood differ from the aforementioned concepts in that its task is 'to provide sophisticated understandings of children and childhood and our obligations to children themselves' (Bunge 2016:97). It may also be described as theological anthropologies of children. The concept theologies for children refers to a form of theology prescribed for children, for example in catechesis (Bunge 2006:570). Children's theology refers to the content of children's own theology (Bunge 2006:570). The concepts of theologising and philosophising with children want to recognise the aspect of equal and mutual meaningful interaction of children and adults in this process. Theologising with children is an established concept, especially in Germany, primarily used in religious education to enhance 'a hermeneutics of active acquisition rather than transmittal' (Zimmermann 2015:1). In doing theology with children, all adult theologians are challenged not to confuse all these nuances of relating children and theology with each other, but rather to develop a clear understanding of what exactly is the focus and/or goal is of doing their theology with children. In this article theologising with children is used in broader sense than in religious education. Here it is used to describe any theological interaction or conversation between adults and children, 
with special reference to adult theological research that interacts with children. The researcher's view is that doing theology with children should not be confined to religious education but rather be broadened to become an important aspect of all theological disciplines. How we combine the words 'theology' and 'children' does not matter as much as practicing any of these combinations, and this implies that adult theologians should listen to children.

\section{The challenge of listening to children}

Despite the growth of child theology, theologies of childhood and a childist approach to the interpretation of the biblical texts since the beginning of the 21st century, most of the literature mainly focussed on how adults think about children and childhood. When a biblical scholar studies the biblical texts with a childist approach, mostly only 'children's agency and contributions to the text and its world' are explored (Parker 2019:139). Children themselves are rarely included as co-theologians in the exploration and interpretation of the text. This is one of the main differences between childist and feminist studies. In feminist studies women themselves are the researchers. Furthermore, the agency of children as participators in doing theology in most of the other theological sub-disciplines is not always taken seriously. Even when doing child theology, it often stays an adult exercise in which the voices of actual children are not included. Furthermore, '[a]ttempting to hear them is fraught with peril: often we think we hear their voices when we really are hearing only ourselves and our attentions for children' (Jensen 2005:xii). Coles (1990), the eminent scholar of the spiritual life of children, emphasised the importance of really listening to children when he wrote the following:

Years later, when as I look back and go over old transcripts. I realize that the children I met were eager indeed to speak of their religious and spiritual interests, concerns, worries, beliefs but the doctor listening to them had his own agenda, some of it a consequence of a professional ideology all too well learned. (p. 340)

Indeed, it can also happen with us as theologians. Therefore, the utmost importance is that we shall really listen, regularly, to the voices of real children. As long as childist or child theology only listens to our own voices or/and other adult voices without taking children's own voices into consideration, it is inclined to become self-absorbed adultism.

Therefore, adult theologians should take Koepf Taylor's (2013:128) suggestion of consulting children as 'valid meaning-makers in the interpretation of Scripture' more seriously. Briggs (2017:3) also emphasised that it is time that we give 'child readers a voice to articulate their readings of the Bible'. A good example of giving children a voice is Briggs' (2017) own research on children's reading of the Gospel of Luke. In her research sample she included children aged between 12 and 14 years. Betsworth (2019:10, 18-19) also did childist research on the Gospel of Luke by including several children from different ages in her reading of Luke 9:37-43. One group consisted of children between 11 and 13 years old and another group included children aged between 11 and 14 years. She also involved two groups of children aged from 5 to 12 years.

The challenge for the future is to include more younger children aged between 6 and 12 years, a stage of development which is often referred to as 'middle childhood' (cf. Davies 2011:327-383), in doing theology, not only in the biblical sciences but also in all theological disciplines. White and Willmer (2006:19), two of the ground-breaking child theologians of the 21st century, admitted that '[h]ow children and young people have been, are and will be engaged in the process is one of the more pressing issues CTM [Child Theology Movement] faces'. That it is still a pressing issue and challenge is illustrated by the publication of this collection of articles. The challenge for adult theologians is still to involve children, responsibly, ethically and with much caution, in doing theology so that any form of childist or child theology could become authentic theology informed by children.

The situation in theology, as described above, is very much like the situation in the church 'where children are often made acutely aware of being "non-persons" until a certain age or ritual, or until they are finally allowed access to a certain sacrament' (De Beer 2016:215). They are only seen, at least theoretically, as spiritually mature persons after confirmation. It seems as if there are adult theologians who have this same orientation towards children: they are 'nonpersons' or 'non-theologians', spiritually not matured. Listening to them is not important until they reach a certain age. This attitude and behaviour of 'not-listening' to children has, maybe, to do with our conceptions of childhood.

\section{The challenge to scrutinise our conceptions of childhood Concept and conceptions}

It seems as if one of the biggest challenges for us as adult theologians is to honestly scrutinise the constructions of childhood with which we are operating. We all have our own presuppositions, images and assumptions about children and childhood that are not always concurring with God's view of children (Richards 2009:xxii). Regarding our views of children, Wyse (2004:211) stated: 'The way that we view children in general is directly linked to the way we deal with them practically and specifically'. This statement indicates that the way we handle children in society, in our families, in the school, in the church and in the state is influenced by the way we think about children. In this regard, Elkind (1993; cf. Elkind 1998:1) made a very important comment, which is as follows:

The child is a gift of nature; the image of the child is man's creation. The image of the child, rather than nature's gift, determines educational practice in any historical epoch. (p. 5) 
The implication is that adults' relations with children and the way they treat them depend on their subjective ideas, images and metaphors they use in connection with children. These ideas about children are a social construct, a way by which we integrate all the facts we know about children to help us to understand childhood (Archard 2004:25). The social construct 'childhood' is not static. It changes over time, differs from society to society and even between different ethnic, economic and social groups in the same community (Heywood 2001:4, 9). The result is that there are at any stage a variety of understandings of childhood present in every society (Olson 2001:21). Mercer (2005) stated the following:

[E]very society, culture, and historical period constructs and embodies its own peculiar understanding of childhood. Amidst competing perspectives of what a child is, certain understandings rise up when they find support from dominant social, political, economic, and religious trends that reinforce them. (p. 4)

This is also applicable on theology, adult theologians and the way we deal with children in doing theology: our view of children determines their inclusion or exclusion in the way we do theology. Therefore, it is important for adult theologians to attend deeply to their own understanding of childhood. In this regard, it is important to take Archard's (2004) following differentiation between 'concept' and 'conceptions' into account:

In simple terms, to have a concept of 'childhood' is to recognise that children differ interestingly from adults; to have a conception of childhood is to have a view of what those interesting differences are. I have the concept of childhood if, in my behaviour towards children and the way I talk about them, I display a clear recognition that they are at a distinct and interestingly different stage of their lives from adults. I have a particular conception of childhood in so far as my treatment of children and discourse concerning them reveals a particular view of what specifically distinguishes children form adults. (pp. 27-28)

Although all theologians should work with a concept of childhood which recognises that children differ from adults, it is often adult theologians' conceptions of childhood, the way they define the difference(s) between children and adults, that differ in many ways and contributes to the neglect of children in doing theology.

Although there are exceptions, the conceptions of childhood of many people, including theologians, are based on different ways of comparing children and adults with one another. The implication is that childhood is then defined as the 'culture other' of adults (Prout 2005:10). One way of doing this is to base our thinking about childhood on what is essential to be an adult (Archard 2004:29). People compare children with adults and define childhood in terms of what children lack (cf. Grobbelaar 2008:420-421). This comparison approach implies that adulthood becomes the norm for being a human being and it leads to the view that children are incomplete or undeveloped versions of adulthood, not yet fully human, lacking the wholeness of adulthood, immature, incompetent, irrational and, therefore, an adult or human being in waiting, 'a "not-yet-adult" or an "adult-to-be"' (Asbridge 2009:5). Although these views are not applicable to all aspects of children's lives and vary from culture to culture, the consequence is that adults usually become responsible to care for them or educate them to become less fragile, more mature, competent, rational, civilised and thus full human beings. It leads to a hierarchical relationship characterised by child dependency, of adult teacher to pupils, rather than to a relationship of equal participators in doing theology.

Another way of comparing children and adults, based on the pretended innocence of children, defines childhood in the opposite way. Childhood is then defined according to what adults are not, but what is part of childhood, as Higonnet (1998:224, 209) indicated, children are 'not sexual, not vicious, not ugly, not conscious, not damaged', as adults are. This view of children makes it almost impossible to take children's agency and theological capabilities seriously enough to do theology with them.

\section{A low view of childhood}

The above understanding of childhood could be called a 'low view of childhood' (cf. Berryman 2009). Berryman discusses different theologians' understandings of childhood according to different time frames in the history of the church. In this historical overview, Berryman (2009:95-98; 147-155; 161-166) identified some theologians (Martin Luther, Friedrich Schleiermacher, Horace Bushnell and Rowan Williams) who had a high view of childhood, which is defined as 'respectful to, moves toward, and is open to learning from children' ( $\mathrm{p}$. 204). But Berryman (2009:46-49; 54-59; 73-76; 104-109; 122 $124 ; 137-140)$ also identified in the history of theology a low view of childhood (Origen, Augustine, Peter Abelard, Richard Hooker, John Bunyan and Jonathan Edwards) which is defined as 'dismissing of, moves away from, and only sees children in a narrow, closed way, as objects to be taught and purified' (Berryman 2009:204). Berryman (2009:25, 203-213) also distinguished between three threads through the history of theology that were an expression of this low view of childhood and which lead to the exclusion of children in doing theology: ambivalence, ambiguity and indifference.

According to Berryman (2009:203), ambivalence 'refers to holding two mutually conflicting feelings... at the same time' and it is used by him to indicate the combination of 'delight and aversion, attraction and repulsion, and a movement toward and away' from children. This ambivalence towards children seldom leads to meaningful inclusion of children in doing theology.

Ambiguity, according to Berryman (2009:25), is not about emotions as in ambivalence, but rather about logic which apprehends the word children in more than one way. 'When ambiguity is combined unconsciously with ambivalence the two themes work together to paralyze our best thinking about children in the church today' (Berryman 2009:25). The conflicts between ambiguity and ambivalence mostly lead 
adult theologians to exclude children from involvement in doing theology with them.

The third tread of indifference towards children 'can be neutral but it can also drift into being unconcerned, apathetic, or even turn into a smirk or sneer about children' (Berryman 2009:25). This neutrality, or lack of interest or concern, or sometimes even adversity towards children, usually enhances the exclusion of children from any participation in doing theology together with adults. It is as if children become almost invisible in theology.

It seems that a negative view of childhood influenced and is still influencing our theological conceptions of childhood, excluding children as agents of theology. Especially, indifference towards children in theological thinking, and thus the absence of children in many dominant theologies, had a huge influence over many decades. In this regard Bunge (2006) stated the following:

Despite the rising concern for and curiosity about children, scholars of religion, theologians, and ethicists across religious lines have had little to say about children, and they have had little to contribute to the growing political and academic debates about children or our obligations to them. Many have not treated childhood as a topic meriting serious attention.... (p. 551; cf. ed. Bunge 2001:3, 2004:43; DeVries 2001:162)

About this situation, Miller-McLemore (2003:xxii) declared: '[a]fter Horace Bushnell, well known for his mid-19thcentury theology of childhood, the door slammed shut on children as a respectable topic'.

\section{Some examples of a low view of childhood}

To give concrete examples of the presence of a low view of childhood amongst theologians is a difficult exercise. Many theologians did not totally ignore children in their theological writings, they may even have written much about children and children's ministry, about parenthood and caring for children, about ethical issues regarding children. Therefore, it is important to understand that the question to answer here is not whether they wrote about children, but rather what view of childhood came to the fore in their theological work. The inclusion of a specific theologian in this section may be seen as an arbitrary decision. Therefore, more attention is given to the possible trends in some theological fields than just focussing on individual theologians. Wherever the name of an individual theologian is mentioned in this research, it is based on the review of the literature used here.

\section{Systematic theology}

Miller-McLemore (2005) declared, in general, the following about Systematic Theology:

When systematic theologians of the last century spoke about human nature and redemption, they meant, without hesitation, adult nature and adult redemption... Children have simply not been proper subject matter for theology, not because they were unimportant but, more simply, they had vanished from the sight of the typical male theologian.... (pp. vii-vii)
This view is confirmed by Bunge (2001:11) stating that although some 19th-century theologians, such as Schleiermacher and Bushnell, gave much attention to children in their theological reflections, it was mostly not carried out by systematic theologians of the 20th century. Surely, the theological thoughts of 20th-century systematic theologians, such as Karl Barth and Karl Rahner, include views which may be enriching for our care for and understanding of children of our day (cf. Berryman 2009:154-161; Bunge 2001:386-445; Konz 2016). 'However, even they, like most theologians today, did not develop full-fledge teachings about children or their spiritual formation, and their attention to children is minimal' (Bunge 2001:11).

Berryman's (2009:158) opinion is that 'Barth is largely indifferent to children in his theological work' and he seldom mentions children in his Church Dogmatics (Berryman 2009:156). In his main work on theological anthropology presented in Church Dogmatics III/2, Barth does not give direct attention to children (Konz 2017:141). According to Berryman (2009:156,157), Barth viewed the time of childhood only as a time of preparation for adulthood and for theological understanding. Only thereafter can they make any worthwhile contribution to the ministry of the church. Once Barth, after having clarity about a theological issue, even said that 'he had recovered from "the children's disease of being ashamed of theology"' (Berryman 2009:156).

This lack of interest in childhood in theological anthropology was not confined to Barth. Shier-Jones (2007:187) stated that Christian anthropology in general skipped childhood and this fact contributed to the lack of a generally accepted systematic formulation of a theological understanding of childhood in systematic theology. Shier-Jones (2007) also indicated the following:

$[W]$ here childhood has been engaged with theologically, it has tended to be for the sake of some other cause or doctrine. Childhood qua childhood has received little attention from a Church whose primary responsibility has been (metaphorically speaking) to turn the developmental model on its head and convert adults into children, that is, children of God. (p. 188)

Berryman (2009:225) confirms this view by stating that a formal doctrine of childhood is not explicitly part of the identity of any denomination. It seems that a formal doctrine of childhood does not even exist. What exist is rather an informal doctrine operating on the unconscious level of the church and theological thought. It is the de facto doctrine or operative doctrine that influences the life and ministry of the church and our theological thought patterns. According to Berryman's (2009:226) historical analysis, referred to above, the operative doctrine of childhood is primarily ambivalence, ambiguity and indifference.

\section{Youth Ministry}

Ironically, a low view of childhood was also present throughout the history of Youth Ministry. This situation was partly the result of a lack of theological reflection in Youth 
Ministry as science and as practice. More and more calls for a turn to more theological thinking in Youth Ministry came to the fore (cf. Dean, Clark \& Rahn 2010; Root \& Dean 2011). Dean (2010) explains this movement as follows:

What we mean is that while the practice of youth ministry has been with us for quite a while now (70 to 120 years or so, depending on how you count), it has not always been concerned with theological reflection. That is not to say that theology wasn't happening, or that youth workers didn't care about theology. But it is to say the youth workers' actions and self-conceptions were rarely informed by significant theological reflection. In fact, when I started writing about youth ministry...theological reflection with and for young people was rare and awkward. (pp. 15-16; author's added emphasis)

Becker's (2006:10) opinion is that the call to reflect more theologically on youth ministry is the right call. He (p. 10) is concerned that answering to this call is seen as only the task of practical theology and that other theological disciplines ignore this call. Referring to the statement made by Dean (2010) that youth ministry needs systematic and historical theology for a wider conversation and broader context, Becker (2006) asked the following important questions:

If it is true that historical and systematic theology give a broader context to youth ministry, then why do they seem quite invisible in the current flow of youth ministry studies? Why don't Bible scientists, church historians and systematic theologians seem to be provoked to contribute to the academic study of youth ministry? (p. 11)

But the presence of a low view of childhood in Youth Ministry does not only come to the fore in the lack of theological reflection in and about Youth Ministry but it also comes to the fore in the lack of theological reflection with youth (cf. Dean 2010). Dean (2010) clearly stated this view as follows:

Unfortunately, youth ministry has been reluctant to invite young people into this level of theological thinking. We tend to view young people as consumers of theology rather than as people who help construct religious discourse. We are far more likely to consider youth objects of ministry rather than agents of ministry; people to be ministered unto rather than people Jesus has called into ministry in their own right. We think teenagers need theology added to them... (p. 31)

Sims (2005) identified the same tendency in his research stating the following:

Children generally have not been viewed as active agents in the process of interpreting, constructing, negotiating and defining their relationships, societies, cultures, families and churches. Theologically they have not been viewed as active, formative agents in their relationships with God, others, themselves, society and culture, but rather as passive recipients of formation for such relationships or as young, immature sinners in need of conversion. (p. 11)

Actually, it is the other way around; theology and adult theologians need teenagers and younger children to enrich our theological perspectives. The challenge before us as adult theologians is to find ways to change the objectification of our youngest people in theological reflection to a resubjectification of them that they can be agents of theological thinking together with us. Also, in the field of Youth Ministry as science and as ministry we need the input of the younger generation.

\section{Church history}

Low views of childhood also come to the fore in church historians' research on the topic of church and childhood. In 1994, a collection of papers delivered at the Ecclesiastical History Society in England were published (Wood 1994). These papers clearly illustrate how low views of childhood were present in the church throughout history. In her introduction, Wood (1994:xix) noted that the central theme in these papers was that the church's views of children was very much characterised by ambiguity. As discussed above, ambiguity reflects a low operative view of childhood.

\section{Multi-dimensional theology of childhood}

Behind these low views of children and childhood discussed above, there is usually a one-sided and unbalanced theology of childhood. In her work on theologies of childhood, Bunge (2004:45-50, 2006:53-68, 2011:20-30) identified the following six important and almost paradoxical biblically based perspectives on childhood:

- gifts of God and sources of joy

- sinful creatures and moral agents

- developing beings who need instruction and guidance

- fully human and made in the image of God

- models of faith and sources of revelation

- orphans, neighbours and strangers in need of justice and compassion.

Although these perspectives are not exhaustive of the biblical witness about children and can also be formulated in other ways (cf. Konz 2014:24; Miller-Mclemore 2003; Richard 2013), we should take note of Bunge's (2016:100101) important emphasis that the multi-dimensional biblical perspectives should be held together in developing and maintaining a vibrant view of childhood. She added the following (Bunge 2016):

[T] his complex view of children also honours the complexity of child-adult relationships and adult obligations towards children emphasising that adults are not only to protect, provide and teach children but also to enjoy, respect and learn from them. (p. 101)

In general, a low view of children, as mentioned above and indicated by Bunge (2016) is the result of the difficulty of holding onto the complex nature of the Biblical witness regarding a theology of childhood. It is easier to adhere to a more simplistic and one-sided view of childhood. Sometimes the result is that children are viewed as spiritually immature, and only adults can be spiritually matured. The possible logic behind this, or reason for this view, is that we think children do not have spiritual insights, cannot formulate and 
communicate logically on the level of adult theologians and cannot contribute to the enhancement of theology. Therefore, they cannot be equal partners with adults in doing theology. To do proper theology, it is rather better to exclude children from this process. This type of reasoning can be characterised as the 'adultisation' of spirituality and faith (cf. Thatcher 2010:140).

Embarking on a way of doing theology with children, our views of children and childhood could be challenged. We have to honestly and rigorously scrutinise our own views of childhood. What are our operative ways of thinking about children? In what ways are our conceptions of childhood influenced by our own experiences of childhood and by our surrounding culture? How does the Bible influence our thinking? At least, we are challenged to 'reimagining children' (Miller-Mclemore 2003:xxvi). In reimagining children, Miller-Mclemore's (2003:xxiii) main thesis is that 'children must be fully respected as persons, valued as gifts and viewed as agents'. To reach this point may ask from us as adult theologians a huge change.

\section{The challenge to be converted}

It is only when we change, when we are liberated from our low views of childhood that we are able to include children as co-theologians in doing theology. The crucial question is: how can this liberation occur? There is no simple answer to this question. As indicated at the beginning of this article, it can only start with a conversion, actually a multi-faced conversion, a change in our thinking, doing and living of our views of children, theology and research.

The biggest challenge is to change, be converted and become like a child before we can welcome children as our cotheologians in doing theology. As Jesus taught his disciples, the only 'greatness' in his kingdom is to become people without any worldly status (Mt 18:1-4).

Grobbelaar (2012) states the following:

As theologians, we should change and become like children and do our theology as children in God's kingdom. The implication is that we should follow Jesus' example of a kenosis identity doing our theology and living out our identity on the margins of society, where many children find themselves, rather than from the centre of the theological power positions in our churches and theological schools. (p. 10)

This conversion to the margins will also affect our understanding of what human knowledge is and how we obtain it.

\section{The challenge of an epistemological break}

Doing theology with children asks from us an epistemological break (Botha 2016). It requires us 'to understand and accept an entirely different way of knowing and of obtaining knowledge, especially of God and God's kingdom'
(Grobbelaar 2016c:71; cf. Botha 2016:1). For too long theology has been performed abstractly from above (Bosch 2011:433) as the mind games of the professional 'faith-elite' expressed in books and dissertations, stored away from life behind the walls of libraries without considering the oppressive realities of our world. But an important change to "theology "from below," "from the underside of history"' (Bosch 2011:433) has started to occur. For this changed 'angle of vision' Van den Berg and Pienaar (2005:98-99) stated that they prefer to use the expression 'ground-up'.

Doing theology with children can only be carried out with a 'ground-up' angle of vision. Therefore, we as adult theologians must accept the challenge to abandon our academic pedestals and titles and enter the harsh realities of the world of children in a childly, not childish, way, willing to listen to them, looking to the world from their position, ground-up and communicating with them, not in the highly intellectual and scientific discourse of the academic world but in their language: play and playfulness (cf. Landreth 2002:16). To achieve this goal, we shall have to acknowledge children as our guides, being agents of faith and sources of revelation for us, as illustrated in Matthew 21:12-17 (Grobbelaar 2016c:71-73). The challenge is to sit with them in a circle of equals, asking wondering questions instead of Socrates-style questions, using physical artefacts which they can move around to communicate their ideas, doing a spiritual exercise with them rather than a scientific academic conversation, allowing them to focus on the meaning of the text for them instead of the text's meaning in itself (cf. Berryman 2013:Loc. 4277-4308).

We may be pleasantly surprised by the children's understanding of Scripture when we give them freedom to interpret the text for us. One of the important findings by Betsworth (2019:22) in her research on reading the Gospel of Luke with children, referred to earlier in this article, was that the children with whom she read this text came to similar conclusions to those made by herself through her scholarly, exegetical process, 'demonstrating that young people can draw meaningful conclusions about the biblical text based on their own experiences and when they are creatively guided through the narrative'.

In the Child Theology Movement, this epistemological break was implemented in an experimental way of doing theology (cf. Willmer 2007). A process of doing theology in three phases was developed (White 2010:159-160). In the first phase all participants formulated their own understanding of the topic they were discussing. In the second phase a child is placed in the midst of the participants. Sometimes it is a real child, but not always. White (2010) said about this phase as follows:

This part of the experiment does not require actual children in the midst: [I]t can involve acts of imagination, stories, and the sharing of the personal experiences of children and childhood in a particular culture. (p. 159) 
After this phase, the participants revisit their initial understanding of the topic and adjust it in the light of what the 'child in the midst' shared with them.

Doing theology with children challenges adult theologians to change the way they see generation of knowledge. It is not a process from above but rather a process from the ground up, seeking together with children on the same ground level for theological insight and knowledge. Our involvement with children can vary in many ways leading to various results and, therefore, we have to look more deeply into the possible ways of involving children in our theologising with them. Maybe we have to ponder the possibility of developing a continuum of ways of generating knowledge in doing theology with children.

\section{The challenge of discerning a continuum of doing theology with children}

When we start to involve children in our theologising, it is of paramount importance that we take cognisance of the contribution made by Swartz and Nyamnjoh (2018) on doing research with the aim of enhancing social justice. Of such research they stated the following:

Usually, when we think about research with such an impact, it is participatory research that comes to mind, with its emphasis on the practicality of knowledge production and the cultivation of partnerships between researchers and those researched. Such a view obscures a spectrum of inquiries, such as interactive and emancipatory research which have varying impacts when producing knowledge on social justice and marginality. (p. 1)

In this regard, they argued convincingly that there exists a continuum of such research varying from interactive through participatory to emancipatory research. Fundamentally, according to Swartz and Nyamnjoh (2018), all these methods of research do the following:

[S]hare a commitment to inclusivity and engagement in the research process. What the continuum does is to suggest differentiating these methods as forms of inquiry with varying degrees of inclusion, power and ownership... In interactive research, inclusion is modest, and the researcher retains power and ownership of the research. Participatory research is characterised by greater inclusion, shared power and ownership, whilst in emancipatory research the researcher relinquishes power and ownership, and inclusion is a sine qua non and changes as the process proceeds. (p. 3)

This continuum of research can help us to understand the current existing knowledge in this field, and also in advancing doing theology with children. The growing awareness of children amongst theologians during the last few years has brought about new theological outputs focussing on children. But much of this theologising is still adults speaking about children, which, although focussing on children and taking their needs into account, is not even an interactive way of doing theology with children.
Even the experimental way of doing theology developed by Child Theology Movement, although putting children in the midst in various ways, seldom breaks through to an interactive way of doing theology with children. Some biblical scholars, such as Betsworth (2019) and Briggs (2017) referred to above, ventured in doing interactive theology with children in the interpretation of Biblical texts. Very rarely does doing theology with children become participatory or emancipatory ways of including children.

As adult theologians we can no longer avoid the challenge of honestly evaluating our own way of doing theology with children on the basis of the above continuum. We have to ask ourselves the important question: where does my way of doing theology and theological research with children fits on this continuum? Is it interactive, collaborative or emancipatory? Or is it not even part of this continuum, lingering only in the space of doing theology about children? We still have so much to learn in order to move into interactive and participatory ways, and even more to move into emancipatory ways of doing theology which really include and liberate children. Much more research is needed on this topic.

\section{The ultimate challenge}

As adult theologians, we still have to hear clearly, and give urgent attention, to Asbridge's (2009) following clarion call:

Without the participation of children, not simply their presence, the Church and society as a whole, is as incomplete as when it excludes the poor or the sick. Theology needs to be challenged by the vision, perspective and experience of children. Theology is often a very adult discipline composed of a sophisticated language about God. Much theology is that of the white, male, western adult and carries prejudices and preconceptions from those genres. Today traditional Christian theology is enhanced and challenged by many different voices and perspectives: from liberation theology, feminist and womanist theology, Korean Minjung theology, and other liberation and third world theologies. Yet even so, the theological insights of children do not intrude. Theology remains the province of adults talking to and about other adults about the nature of the supreme adult which is God.

Yet children have to tell us about God, for God calls them from their earliest beginnings and walks with children down the years. This experience of God informs children's spirituality and prompts its growth... (p. 20)

We as adult theologians must hear from children about their perspective and experiences with God. Without it, our perspective and understanding of God is only partial. Therefore, we have to move away from the objectification of children in our theological research to re-subjectify children of doing theology with an approach of mutual subjectivity (Konz 2017). But, where do we start with the process of doing theology with children? What Rowland (2007) said about liberation theology can also be applied on doing theology with children: 
Rather than learning about doing theology with children you first have to start doing it. The only way to learn it is by embarking on it. It is not a body of information that you have to acquire, but rather a way of living to pursuit. (p. 4)

We have to venture outside our comfort zones and traditional ways of doing theology and start doing theology with children in the spaces where they are present. The wonderful news is that when we welcome children to do theology with us, we actually welcome Jesus in our midst (Mt 18:5; cf. Grobbelaar 2016d). When that happens, we shall echo the words of Jesus: 'I thank you, Father, Lord of heaven and earth, that you have hidden these things from the wise and intelligent and revealed them to infants' (Mt 11:25).

\section{Acknowledgements Competing interests}

The author declares that no financial or personal relationships exist which may have inappropriately influenced the writing of this article.

\section{Ethical considerations}

This article followed all ethical standards for a research without direct contact with human or animal subjects.

\section{Funding information}

This research received no specific grant from any funding agency in the public, commercial or not-for-profit sectors.

\section{Data availability statement}

Data sharing is not applicable to this article as no new data were created or analysed in this study.

\section{Disclaimer}

The views and opinions expressed in this article are those of the author and do not necessarily reflect the official policy or position of any affiliated agency of the author.

\section{References}

Archard, D., 2004, Children. Rights and childhood, 2nd edn., Routledge, London.

Asbridge, N., 2009, 'What is a child?', in A. Richards \& P. Privett (eds.), Through the eyes of a child. New insights in theology from a child's perspective, pp. 1-20, Church House, London.

Becker, R., 2006, 'Beyond a godless understanding of youth: Why exegesis matters to youth ministry', Journal of Youth and Theology 5(1), 10-30. https://doi. org/10.1163/24055093-90000253

Berryman, J.W., 2009, Children and the theologians. Clearing the way for grace, Morehouse, New York, NY.

Berryman, J.W., 2013, 'Theologizing with children - A parable approach', in B. Hyde (ed.), The search for a theology of childhood - Essays by Jerome W Berryman from 1978-2009, Loc. 4250-4629, Modotti Press, Ballarat, Kindle edn.

Betsworth, S., 2019, 'Jesus (and) the only child: Jesus, children and the Gospel of Luke', in J.P. Grimshaw (ed.), Luke-Acts, pp. 9-22, Texts@Contexts, T \& T Clark London.

Betsworth, S. \& Parker, J.F. (eds.), 2019, T \& T Clark handbook of children in the Bible and the Biblical World, T \& T Clark, London.

Bosch, D.J. 2011, Transforming mission: Paradigm shifts in theology of mission, Orbis Books, Maryknoll, New York, NY.
Botha, N., 2016, 'Children as theological hermeneutic: Is there a new epistemological break emerging?', HTS Teologiese Studies/Theological Studies 72(1), a3110. https://doi.org/10.4102/hts.v72i1.3110

Briggs, M.R., 2017, How children read Biblical narrative: An investigation of children's readings of the Gospel of Luke, Pickwick, Eugene, OR, Kindle edn.

Bunge, M.J., (ed.), 2001, The child in Christian thought, William B. Eerdmans Publishing, Grand Rapids, MI.

Bunge, M.J., 2004, 'Historical perspectives on children in the church: Resources for spiritual formation and a theology of childhood today', in D. Ratcliff (ed.), Children's spirituality. Christian perspectives, research and applications, pp. 42-53, Cascade Books, Eugene, OR.

Bunge, M.J., 2006, 'The child, religion and the academy. Developing robust theological and religious understandings of children and childhood', Journal of Religion 86(4), 549-579. https://doi.org/10.1086/505894

Bunge, M.J., 2008, 'Introduction', in M.J. Bunge, T.E. Fretheim \& B.R. Gaventa (eds.), The child in the Bible, pp. xiv-xxvi, William B. Eerdmans, Grand Rapids, MI.

Bunge, M.J., 2011, 'Biblical understandings of children and childhood: Resources for the church and mission today', in K.J. White (ed.), Now and next, a compendium of papers presented at the Now \& Next theological conference on children, Nairobi, Kenya, 9-12th March, pp. 15-35, Compassion International, Colorado Springs, CO.

Bunge, M.J., 2012, 'Biblical and theological perspectives and best practices for faith formation', in K.E. Lawson (ed.), Understanding children's spirituality. Theology, research, and practice, pp. 4-25, Cascade Books, Eugene, OR, Kindle edn.

Bunge, M.J., 2016, 'Task, sources and significance of theologies of childhood, in J. Grobbelaar \& G. Breed (eds.), Theologies of childhood and the children of Africa, pp. 92-112, AOSIS, Cape Town.

Coles, R., 1990, The spiritual life of children, Houghton Mifflin, Boston, MA.

Cooey, P.M., 2010, 'Neither seen nor heard: The absent child in the study of religion', Journal of Childhood and Religion 1(1), 1-31.

Davies, D., 2011, Child development: A practitioner's guide, 3rd edn., The Guilford Press, New York, NY

Dean, K.C., 2010, 'Fessing up: Owing our theological commitments', in K.C. Dean, C. Clark \& D. Rahn, (eds.) Starting right: Thinking theologically about youth ministry, pp. 28-40, Youth Specialities, Zondervan, Grand Rapids, MI, ePub edn.

Dean, K.C., Clark, C. \& Rahn, D. (eds.), 2010, Starting right: Thinking theologically about youth ministry, Youth Specialities, Zondervan, Grand Rapids, MI, ePub edn.

De Beer, S., 2016, 'Child-inclusive cities: Towards a liberating praxis with children', in J. Grobbelaar \& G. Breed (eds.), Welcoming Africa's children - Theological and ministry perspectives, pp. 210-234, AOSIS, Cape Town.

DeVries, D., 2001, 'Toward a theology of childhood', Interpretation 55(1), 161-173. https://doi.org/10.1177/002096430005600205

Elkind, D., 1993, Images of the young child. Collected essays on development and education, National Association for the Education of Young Children, Washington, DC.

Elkind, D., 1998, Reinventing childhood. Raising and educating children in a changing world, Modern Learning Press, Rosemont, IL.

Elkins, K.G. \& Parker, J.F., 2016, 'Children in Biblical narrative and childish interpretation', in D.N. Fewell (ed.), The Oxford handbook of biblical narrative, pp.422-433, Oxford University Press, New York, NY.

Garroway, K.H., 2018, Growing up in ancient Israel: Children in material culture and Biblical texts, SLB Press, Atlanta, GA.

Grobbelaar, J., 2008, 'Die bediening aan laerskoolkinders in en deur die gemeente as ' $n$ intergenerasionele ruimte', Unpublished DTh dissertation, Department of Practical Theology and Missiology, University of Stellenbosch, Stellenbosch.

Grobbelaar, J., 2012, Child theology and the African context, Child Theology Movement, London.

Grobbelaar, J., 2016a, 'Resources on theology and children', in J. Grobbelaar \& G. Breed (eds.), Theologies of childhood and the children of Africa, pp. 1-50, AOSIS, Cape Town.

Grobbelaar, J., 2016b, 'The grammar of combining the vocabulary of theology, children and Africa', in J. Grobbelaar \& G. Breed (eds.), Theologies of childhood and the children of Africa, pp. 51-91, AOSIS, Cape Town.

Grobbelaar, J., 2016c, 'Doing child theology: History and methodology', in J. Grobbelaar \& G. Breed (eds.), Theologies of childhood and the children of Africa, pp. 42-87, AOSIS, Cape Town.

Grobbelaar, J., 2016d, 'Jesus and the children in the Gospel of Matthew', in J. Grobbelaar \& G. Breed (eds.), Theologies of childhood and the children of Africa, pp. 132-186, AOSIS, Cape Town.

Gutierrez, G., 1990, The truth shall make you free, transl. M.J. O'Connell, Orbis Books, Maryknoll, NY, Kindle edn.

Hendrick, H., 1992, 'Children and childhood', ReFresh 15(Autumn), 1-4.

Heywood, C., 2001, A history of childhood: Children and childhood in the west from medieval to modern times, Polity Press, Cambridge.

Higonnet, A., 1998, Pictures of innocence: The history and crisis of ideal childhood, Thames Hudson, London.

Iversen, G.Y., Mitchell, G. \& Pollard, G., 2009, 'Starlings and theologians', in G.Y. Iversen, G. Mitchell \& G. Pollard (eds.), Hovering over the face of the deep.
Philosophy, theology and children, pp. 11-12, WaxmannVerlag, Munster, Google Books edn. 
Jensen, D.H., 2005, Grace vulnerability. A theology of childhood, The Pilgrim Press, Cleveland, $\mathrm{OH}$.

Koepf Taylor, L.W., 2013, Give me children or I shall die: Children and communal survival in Biblical literature, Fortress Press, Minneapolis, MN, Kindle edn.

Konz, D.J., 2014, 'The many and the one: Theology, mission and child in historical perspective', in B Prevette, K.J. White, C.R. Velloso Ewell \& D.J. Konz (eds.) Theology, mission and child. Global perspectives, vol. 24, Regnum Edinburgh Centenary Series, pp. 23-46, Regnum Books International, Oxford.

Konz, D.J., 2016, 'The child in relation to God, with reference to the theology of Kar Barth', Unpublished PhD dissertation, University of Aberdeen, Aberdeen.

Konz, D.J., 2017, 'Karl Barth's theological anthropology as a resource for overcoming the objectification of children in mission', in V. Kozhuharov \& J.J. Knoetze (eds.), Conversion and transformation: Children and youth in mission contexts, pp. 136-150, Christian Literature Fund, Wellington.

Landreth, G.L., 2002, Play therapy: The art of the relationship, 2nd edn., Routledge, New York, NY.

Mercer, J.A., 2005, Welcoming children. A practical theology of childhood, Chalice Press, St. Louis, MO.

Miller-McLemore, B.J., 2003, Let the children come. Reimagining childhood from a Christian perspective, Jossey-Bass, San Francisco, CA.

Miller-McLemore, B.J., 2005, 'Introduction', in D.H. Jensen (ed.), Grace vulnerability A Theology of childhood, pp. vii-x. The Pilgrim Press, Cleveland, $\mathrm{OH}$

Nolland, J., 1993, Luke 9:21--18:34, Word Biblical Commentary, Word Books, Dallas, TX.

Olson, D.C., 2001, Out of the basement. A holistic approach to children's ministry, Discipleship Resources, Nashville, TN.

Parker, J.F., 2019, 'Children in the Hebrew Bible and childist interpretation', Currents in Biblical Research 17(2), 130-157. https://doi.org/10.1177/2476993X18821324

Prout, A., 2005, The future of childhood. Towards the interdisciplinary study of children, Routledge Falmer, London.

Richards, A., 2009, 'Introduction', in A. Richards \& P. Privett (eds.), Through the eyes of a child. New insights in theology from a child's perspective, Church House, London.

Richards, A., 2013, Children in the Bible: A fresh approach, SPCK, London, Kindle edn.
Root, A. \& Dean, K.C., 2011, The Theological Turn in Youth Ministry, IVP Books, Downers Grove, IL.

Rowland, C., 2007, 'Introduction: The theology of liberation', in C Rowland (ed.), The Cambridge companion to liberation theology, 2nd edn., pp. 1-15, Cambridge University Press, Cambridge, Kindle edn.

Shier-Jones, A., 2007, 'The never-land of religion and the lost childhood of the children of God', in A. Shier-Jones (ed.), Children of God. Towards a theology of childhood, pp. 181-205, Epworth, Peterborough.

Sims, D.A., 2005, 'The child in American evangelicalism and the problem of affluence: $A$ theological anthropology of the affluent American-evangelical child (AAEC) in late modernity', Unpublished PhD dissertation, University of Durham, Durham.

Swartz, S. \& Nyamnjoh, A., 2018, 'Research as freedom: Using a continuum of interactive, participatory and emancipatory methods for addressing youth marginality', HTS Teologiese Studies/Theological Studies 74(3), a5063. https://doi org/10.4102/hts.v74i3.5063

Thatcher, A., 2010,'Beginning again with Jesus', in A. Dillen \& D. Pollefeyt (eds.), Children's voices. Children's perspectives in ethics, theology and religious education, pp. 137-161, Uitgeverij Peeters, Leuven.

Van den Berg, J.A. \& Pienaar, S., 2005, 'HIV/AIDS, violence and children: A groundup practical theology from Atteridgeville and Katlehong, South Africa', Practical Theology in South Africa 20(1), 96-108.

White, K.J., 2010, Introducing child theology. Theological foundations for holistic child development, Malaysia Baptist Theological Seminary, Penang.

White, K.J. \& Willmer, H., 2006, An introduction to child theology, Child Theology Movement, London.

Willmer, H., 2007, Experimenting together: One way of doing child theology, Child Theology Movement, London.

Wood, D., (ed.), 1994, The church and childhood, vol. 31, Studies in church history Blackwell, Oxford.

Wyse, D., 2004, 'Interdisciplinary perspectives: The demonization of childhood', in D. Wyse (ed.), Childhood studies. An introduction, pp. 205-212, Blackwell, Oxford.

Zimmermann, M., 2015, 'What is children's theology? Children's theology as theological competence: Development, differentiation, methods', HTS Teologiese Studies/Theological Studies 71(3), Art. \#2848, 6 pp. https://doi.org/10.4102/hts. v71i3.2848 